\title{
Developing methods of knowledge co-production across varying contexts to shape Sustainability Science theory and practice
}

\author{
Kirsten Maclean ${ }^{1}\left[\right.$. Alison Greenaway ${ }^{2} \cdot$ Clemens Grünbühel $^{3}$ \\ Received: 21 December 2021 / Accepted: 23 January 2022 / Published online: 12 February 2022 \\ (c) The Author(s), under exclusive licence to Springer Japan KK, part of Springer Nature 2022
}

\section{Introduction}

Since the valuable contribution to Sustainability Science of the Special Feature: Weaving Indigenous and Sustainability Sciences to Diversify our Methods (WIS2DOM, Vol 11, Issue 1, 2016), knowledge co-production has become a central feature of many sustainability efforts. Global environmental governance networks (e.g., IPBES, Indigenous Peoples' Regional Forum 2019, Forest Peoples Programme) and scientific research forums (e.g., Sustainability Science), call for representative and context-specific strategies for knowledge production (Zurba et al., 2021). Advocacy for Indigenous rights within academia and research institutions has resulted in part to structural change (in some countries) to ensure scientific enquiry protect Indigenous cultural and intellectual property, recognize Indigenous rights to data sovereignty and facilitate negotiated research agreements that stipulate benefit sharing. In Australasia, 'Indigenous Research' is now classified as a 'research field' which recognizes the unique attributes and contributions of this field of science and affords it much greater visibility (see ARC 2020).

Much of this change results from the leadership, advocacy and practice of Indigenous researchers, Indigenous leaders and their non-indigenous allies. Beyond research institutions, Indigenous peoples in Australia, New Zealand

Handled by Osamu Saito, Institute for Global Environmental Strategies, Japan.

\section{Kirsten Maclean}

kirsten.maclean@csiro.au

1 CSIRO Land and Water, Dutton Park, QLD, Australia

2 Manaaki Whenua Landcare Research, Auckland, New Zealand

3 ACIAR, Canberra, ACT, Australia and Canada, and Ethnic groups in Asia, see value in entering into empowering research partnerships for the co-production of knowledge that recognizes, respects and supports their aspirations to develop sustainable livelihood options based on their unique place-based cultural and natural systems (e.g., Woodward et al. 2012, 2020; Johnson et al. 2016; Maclean and Bana Yarralji Bubu Inc. 2015; Zurba et al. 2019). Equitable partnerships can be realized when all those involved aim to draw on diverse knowledge (and skill) systems to create new knowledge to respond to local/regional challenges that result from global change pressures (e.g., climate change, habitat destruction and biodiversity loss, poverty). Such partnerships may also support Indigenous groups to respond to the pressures exerted by the socio-political responses of governments to address 'global challenges' such as those articulated in the Sustainable Development Goals. For example, in Asia, Indigenous groups continue to grapple with (western) donor-led 'development' imperatives that are rarely driven by the intended beneficiaries and thus do not often align with local/regional interests, aspirations and knowledge (Shiva 1993; Bhattachan et al. 2020, Wattimena 2018; Gibson et al. 2018; Tsing et al. 2020).

\section{Innovative partnerships and methods for knowledge co-production}

This Special Feature, Innovative Partnerships and Methods for Knowledge Co-Production to Support Indigenous Cultural and Environmental Management, is the result of an ever-expanding community of practice of Indigenous and non-indigenous researchers committed to research processes, practices and methods that support knowledge partnerships and action systems for innovative Indigenous cultural and environmental management. Importantly, this Special Feature highlights how such knowledge action systems aim to 
weave together diverse knowledge types and networks for knowledge co-production (e.g., Tengo et al. 2014, 2017; Barber et al. 2014; Maclean 2015; Woodward and McTaggart 2019) that reflects local contexts, extra-locale networks and imperatives (e.g., Massey 1991a, b). The Special Feature, itself a product of knowledge action systems, was inspired by two workshops held in pre-Covid 2019, when researchers were still able to gather in person. The first was held at Maanaki Whenua Landcare Research (New Zealand), Auckland; the second, at The Stockholm Environment Institute (Asia), Bangkok. These workshops included some of the authors, and all of the Editors for this Special Feature. We acknowledge that each contributor brings a distinct positionality to their research encounters, to the Special Feature and their paper (see also Maclean et al. 2021a). The Editorial team are non-indigenous researchers committed to enabling the development and expansion of research institutions and practices to support knowledge action systems in appreciation and respect for innovative Indigenous cultural and environmental management. All papers reflect the knowledge co-production practice of co-authorship. Co-authorship makes visible the multiple positionalities, perspectives, and worldviews of all those involved in the relevant knowledge partnerships.

\section{Research partnerships and knowledge action systems evolve from specific contexts}

The papers in this Special Feature highlight how the research partnerships and knowledge action systems evolve from specific contexts. Hill et al (2021) articulate that within Sustainabilty Science, "co-production across scientific and Indigenous knowledge systems has become a cornerstone of research to enhance knowledge, practice, and ethics and to foster sustainability transformation". Co-production processes offer both opportunities and risks for Indigenous people (Hill et al. 2021; Maclean et al. 2021b), given the profound differences in the world views of their non-indigenous partners and the complex and contested histories of colonisation on Indigenous territories (e.g., Maclean 2009; Zurba et al. 2019). Indeed, the benefits that may result from the efforts for knowledge co-production are likely to be lost if they are enacted without consideration of the power imbalance and ongoing impacts of colonization to Indigenous peoples and collaborators (Zurba et al, 2021). Further, although similarities do exist between colonial and postcolonial events in New Zealand, Australia and Canada, the historical differences and contemporary experiences far outweigh those similarities.

When we consider the experiences of Indigenous peoples in parts of Asia concepts of Indigeneity differ (contributions in this Special Feature are derived from work in Indonesia (Salamanca and Biskupska 2022) and West Bengal, India (Carter et al. 2021). Whether a local group is officially classified by a national government as 'Indigenous' affects their access to resources, their participation in decisions, and their status when dealing with government institutions. Inequalities are ingrained and national institutions, whether due to inertia or to preconceived ideas about alternative knowledge systems, find it difficult to deal with Indigenous groups, especially if they are not represented by formal Indigenous representative institutions. Such groups may also find it difficult to deal with the changing principles of international research partners. Until recently, academic rigour, international standards, and 'reportable' data were paramount. Increasingly, however, international researchers elevate diverse knowledge systems, empathetic approaches, and qualitative data to being the gold standard. Co-creation approaches include the need to navigate expectations, trust, and acceptance between Indigenous and/or local groups, traditional research providers, international researchers, and (hopefully understanding) donors - by no means an easy task. The paper contributions that draw on partnerships developed in India (see Carter et al. 2021) and Indonesia (see Salamanca and Biskupska 2022) echo the sentiment of the Special Feature that, if these challenges can be mastered through increased communication, reflexivity, high ethical rigour, and methodological heterodoxy the chances for sustainable outcomes are higher.

Actors within these knowledge action systems (e.g., Indigenous/ethnic group leaders, researchers, industry groups, policy makers and natural systems) continue to develop their own capacity to respond to these challenges and to work within cross-cultural contexts (e.g., Bawaka Country et al. 2016; Harcourt et al. 2021). In the interest of creating common knowledge to respond to these challenges, many of these actors are keen to share their experiences with others. The collection of papers in this Special Feature will be of interest to the diverse readership of Sustainability Science (e.g., researchers, educators, NGOs, policy makers) as they further develop the theory and practice of knowledge co-production (see papers in WIS2DOM) with special attention to the innovative work being conducted in the Asia-Pacific region and Canada. The collection of papers shares insights about specific problem-oriented knowledge co-production partnerships and related research outcomes including in developing country contexts. Several of the papers provide tangible insights into how the partnerships were developed, what research processes were used to support the partnerships to flourish, the kinds of research practices and methodologies that enabled the co-production of knowledge for specific local and/or regional challenges, and an account of the research outcomes. 


\section{Approaches to embrace polyvocality and new ways of doing and being in research partnerships}

A central argument of all contributions to this Special Feature is the need for research approaches to embrace polyvocality and new ways of doing/being in research and partnerships (see Johnson et al. 2016 editorial for WISDOM2). Key to such approaches are innovative approaches to interpret, bridge, apply and distribute power amongst and between diverse knowledge systems (Zurba et al. 2021). Zurba et al. (2021) systematic review of literature (peer-reviewed and grey) on knowledge coproduction (published between 2000 and 2020), identified four interrelated principles across these studies. Principles include: a recognition of the contextual diversity that bounds knowledge co-production processes; the need for pre-emptive and intentional engagement with Indigenous knowledge holders to enable and support co-production; the development of a shared understanding of the purpose of the knowledge co-production; and the direct empowerment of knowledge holders throughout the co-production cycle. Zurba et al. (2021) also identified how approaches to distribute, share, bridge, apply and interpret power are central to the manifestation of these principles and practices. Other papers in the Special Feature echo these principles, albeit with different language and foci.

\section{Institutional recognition for and support of knowledge partnerships for sustainable futures}

One set of papers highlights the central role of institutional recognition for, and support of, knowledge partnerships for sustainable futures. For example, in Australia, Hill and her numerous co-authors (including 70 from the ten Traditional Owner groups from the Martuwarra catchment in the Kimberley region of Western Australia) identify how knowledge co-production processes that foster learning together, that are grounded in Indigenous institutions, and address Indigenous priorities, can improve the adaptive environmental planning and management capacity and experience of the Indigenous institutions (Hill et al. 2021). They present a fascinating case study of the process used to build a 3D map of the Martuwarra river catchment in Western Australia. It highlights how knowledge co-production activities can also improve the accessibility of knowledge and the experiences of the knowledge holders. The activities can strengthen the collective identity and partnerships of Indigenous institutions, and enable them to better enact their cultural governance, management and planning goals.

Harcourt and her colleagues in Aotearoa New Zealand have operationalized the He Waka Taurua framework for a collaborative agribusiness partnership on the East Coast of the North Island (Harcourt et al. 2021). He Waka Taurua, the double-hulled canoe, is a metaphorical framework that elevates Indigenous worldviews, values and practices alongside western science and knowledge. The authors articulate how this framework supports development of co-governance, comanagement and cross-cultural research. However, the coproduction of knowledge is hampered by inherent difficulties of communicating mātauranga Māori (Māori knowledge) within a science dominated arena. They articulate how, in this context, the risk of assimilating world views remains a challenge. Harcourt and colleagues (all of whom are Indigenous Māori) point to changing environmental legislation in Aotearoa New Zealand and associated opportunities for further influence of Te Ao Māori (Māori worldviews) on governance through use of frameworks such as He Waka Taurua.

\section{Research processes to support knowledge partnerships and action systems to flourish}

Another set of papers bring focus to how research processes 'in action' can support knowledge partnerships and knowledge action systems to flourish. For example, Maclean, Woodward and their Indigenous and non-indigenous coauthors in Australia (Maclean et al. 2021a) use and extend the critique of 'positionality' to interrogate and reveal the power that each partner (not just the researchers) brings to a project. They extend the literature on decolonizing methodologies and positionality to illuminate how the set of unique positionalities of the research partners, and the partnership itself, influenced the research and knowledge coproduction process to generate usable knowledge to support the Indigenous-led bush products sector in northern Australia. Their work provides a way for Sustainability Scientists to also consider the legacy of a project-based knowledgeaction-system. They show how interrogating the post-project benefits derived by project partners can provide insights into the project legacy (e.g., knowledge co-production process and co-developed usable knowledge) and the (lasting) project success (or not).

In Aotearoa New Zealand, Greenaway and her Māori and non-Māori colleagues bring focus to the role of non-indigenous researchers to embrace the geographical, cultural and social place in which they find themselves as 'guests'. They discuss the notion of the need for non-indigenous researchers 'to prepare to arrive as guests' in a co-production of knowledge process and to enable this notion as central to 
methodological sensitivities of such work (Greenaway et al. 2021). They present nine signs to help non-indigenous researchers and practitioners to navigate the co-production of knowledge and practices shaping environmental outcomes. This resource supports knowledge action system actors to move towards an unknown knowledge destination, solution or outcome. It may also help groups move beyond the paralysis generated when non-indigenous partners become cognizant of the enormity of devastation their Indigenous partners are working through. Further building on this notion, Blackett and her team of Indigenous and non-indigenous collaborators developed a 'serious game' methodology which helped the hapū (extended kin group) of Tangoio Marae (a Māori gathering place) to prepare for climate change impacts on the East Coast of the North Island of Aotearoa New Zealand (Blackett et al. 2021). The in-situ co-development of the Marae-opoly game was fundamental to achieving the specific needs of the hapū. As guests on this Māori land the research team developed a partnership which enabled pragmatic navigation through a multi-disciplinary research process. Entering this place and research process as respectful guests the team provide insights into climate adaptation opportunities as well as methodological choices for innovative partnerships.

A further contribution on the topic of 'co-production research in action' comes from British Columbia, Canada, where Natcher and his Indigenous and non-indigenous coauthors present a case study of a 'knowledge partnership in action' developed between the researchers and the Saulteau First Nations (Natcher et al. 2021). Importantly, the Saulteau First Nations were very keen to share their experiences with other Indigenous Nations who are also struggling to protect their lands, traditional economies and cultures from uninformed development. Natcher et al. (2021) share scenario planning tools that could be used to mitigate industrial impacts on First Nations subsistence economies. Their work provides insights from Canada into how a methodology (scenario planning), if co-developed, can result in a useful tool for First Nations partners to explore future possibilities and options for the development of local economies and serve as a tool for collaborative learning and conflict management.

\section{Principles and processes to enable and understand knowledge partnerships}

A final set of papers provide principles, a framework and an evaluation process to better enable and understand knowledge partnerships in practice. Staying in Aotearoa New Zealand, Ruwhiu and her collaborators present a Kaupapa Māori research project (an Indigenous research approach that is by, with, and for Māori people) with Kāti Huirapa Rūnaka ki Puketeraki, a Māori tribal community in the South Island of New Zealand (Ruwhiu et al. 2021). They reflect on and share nuanced lessons in building trusting researcher/Indigenous community relationships. Three interdependent principles are also presented, framed within a Kaupapa Māori perspective (a) Toitū te mātauranga (processes of sustaining and valuing Māori knowledges), (b) Whakawhanaungatanga (processes of establishing relationships), and (c) Kotahitanga (processes of unity and collective action). A vital takeaway for Sustainability Science researchers is the challenge to interrogate the power and privilege inherent in normative western methodologies, and those deeply entrenched institutional processes that perpetuate the status quo. As noted in other papers in this Special Feature robust approaches to researcher positionality and responsibility are required. This work suggests that reimagining and reshaping practices at the intersection of Indigenous knowledges and Sustainability Science may enable truly cutting edge, yet responsible science research.

A writing team from Australia, Robinson and her Indigenous and non-indigenous co-authors (Robinson et al. 2021) present a collaborative and adaptive approach to support Indigenous-led evaluations of sustainability research. The approach, developed with Indigenous collaborators, was designed to evaluate cross-cultural knowledge co-production practice and impact with regards to the adaptive co-management of the World Heritage listed Kakadu National Park, Northern Territory, Australia. Their case study provides fertile ground for Sustainability Scientists and Practitioners given the limited examples of knowledge co-production evaluation frameworks for Indigenous-led and cross-cultural research. The co-authors co-developed indicators to monitor the health of knowledge-sharing and co-production practices and used these to facilitate discussions about practice and impact during both the research project, and once it had finished. The research sought to respond to the Indigenous leaders' priorities to manage their traditional estates, resulting in negotiated benefits, and supporting Indigenous-led collaborative knowledge sharing and practice.

Ethical Community Engagement (ECE) was the initial aim of the gender transformative project of Carter and her Indian and Australian colleagues (Carter et al. 2021). The research collaboration was developed between social researchers based in Brisbane (Australia) and practitioners from the non-government, not-for-profit 'Professional Assistance for Development Action (PRADAN)'. PRADAN is an organisation that works with India's rural poor to support disadvantaged communities to "emerge from poverty and lead a life of dignity" (PRADAN 2022). Their work was conducted with poor and marginalized Indigenous women from two villages (Hakimsinan and Chakadoba villages) in the Bankura district of West Bengal, India. Based on ethical engagement foundations, the team co-developed a framework of principles and practices together with women 
from scheduled castes, which led to their empowerment in critical decision processes, better nutrition outcomes for the household, and, ultimately, more sustainable power sharing arrangements, which proved to be more sustainable over the long run. Here, also the acknowledgement of differing knowledge systems was the starting point and the participatory process of defining goals together and identifying analogous practices led to almost immediate uptake and obvious benefits, even for government agencies usually not concerned with such approaches.

\section{Shaping knowledge co-production theory, practices and methods for Sustainability Science}

The papers in this Special Feature bring focus to the reality that place is the locale where historical experiences inform contemporary realities and struggles (Haraway 1988); where past colonial research practices were, and in some places continue to be, enacted (Smith 1999), and where legacies of inappropriate practice persist (de Sousa Santos 2007). However, place also embodies rich cultural practices (Horlings et al. 2020), complex local histories and stories (Le Heron et al. 2020), processes of re-connection and strengthening connection with country (e.g., Maclean and Bana Yarralji Bubu Inc. 2015), the intersection of knowledge networks and knowledge action systems, and new opportunities for knowledge co-production. This Special Feature shares and celebrates innovative partnerships and methods for knowledge co-production that support Indigenous cultural and environmental management. Taken alone, each paper provides an example of a specific partnership embedded within a given context and place within Australia, New Zealand, India, Oceania and Canada. Taken together, the collection of papers provides an opportunity to consider learnings and insights to shape knowledge co-production theory, practices and methods for Sustainability Science that can be used to enrich partnerships and knowledge action systems in other contexts and locations.

Important to note is that each of these papers was written during the various 'lockdowns', constraints and challenges of the 'Covid-19 Era', but the research reported on was co-developed and co-conducted prior to this 'Era'. A pertinent reflection is how Covid-19 has altered the landscape of qualitative research. The inability of researchers to travel and capture thick description and context has resulted in some instances in an acceleration of knowledge co-production processes and outcomes. For example, in developing country contexts, for non-local researchers trusting incountry partners becomes critical, as well as escaping the traditional interviewer-interviewee paradigm. As such the lines are becoming blurred as to who is the researcher and who is the "researched". In some places and situations, this has resulted in an acceleration towards participatory research approaches where knowledge co-production is beginning to emerge. In such instances, research is conducted by 'in country' researchers, sometimes accompanied by the upskilling of representatives of local communities. In other places, the multiple pressures on the lives of community members may mean that potential in-country researchers may have limited time and capacity to undertake such research. Certainly, for some research partners in some contexts, the inability of researchers to travel may create an opportunity to better capture Indigenous voices, where Indigenous people are leading the engagement. However, it is also important to note the risks that these opportunities may also afford to local researchers including additional workload, potential stress related to less experienced researchers and thus potential impacts on personal wellbeing (c.f. Scheyvens et al. 2021). In addition, non-local researchers need to be mindful of the potential limitations of the collected data (Scheyvens et al. 2021) but also should be open to the additional and unexpected richness that may result from the interviews and data collected by local community researchers.

On the whole, this change represents a welcome opportunity for Sustainability Scientists and Practitioners, and particularly for those who focus on supporting and enabling locally derived solutions to global challenges. Such solutions are likely to result from the interaction of diverse knowledges to enact knowledge action systems for change.

This Special Feature brings greater visibility to the criticality of Indigenous knowledges to Sustainability Science. The contributions in this Special Feature extend and build on existing theory about processes for knowledge co-production (e.g., Mach et al. 2020) and reflexive participatory research practice (e.g., Wolf 1996; Muhammad et al. 2015) by bringing focus to the reality that theories, methods and practices of knowledge co-production should be aimed at changing how decisions are made. In some instances, the first step is to reveal who is present and how they are active in any given knowledge action system. Such a first step also reveals the agency of all, rather than the agency of researchers on the 'agency-less researched' (Maclean et al. 2021a). The contributions demonstrate strong evidence of the contributing factors for successful Indigenous-engaged and led knowledge co-production - and the opportunities of this type of science for Sustainability Science specifically. Further, they highlight how such work is occurring within and between institutions and disciplines, and how such work is always personal. To facilitate this, Maclean et al. (2021a) call for all researchers to be cognizant of the positionality that all project partners bring to a knowledge action system (not just researchers). Revealing the power dynamics, multiple subjectivities, priorities and interests of all project 
partners, opens the space for multiple opportunities to evolve from and for the knowledge action system.

The many case studies show how researchers have an important ethical and moral role to ensure their practices unsettle colonial research structures via decolonizing and Indigenist methodologies. This may include, in some instances, careful consideration of entrenched inequality within research disciplines, and the careful attention to the capacity of all those involved to enable a more equal starting point (e.g., researchers build skills to work with communities, Indigenous groups foster self-efficacy and agency via research partnerships-Carter et al. 2021). It may also include the recognition that such learning is not just personal, but also collective (Greenaway et al. 2021). Intentional interventions to confront colonial histories can be enabled via the sharing of histories, truth-telling (with regards to more recent injustices and/or inappropriate research practices), genuine discussions that enable, as Greenaway et al. (2021) eloquently put it, 'glimpses across world views' and the recognition of relational and shared values. We see this throughout the papers where care for (and with) the environment is represented as the responsibility of a collective of human and non-human actors. These framings force revision of practices of peer review, critique, and accountability so that processes enabling more holistic perspectives and the development of Indigenous peoples' knowledge are invested in. Contributors share diverse methodological approaches aimed at relationship building. Visual methods, including the 'serious game of Marae-oply' co-created by Blackett et al. (2021), the future scenarios co-developed by Natcher et al. (2021) and the 3D maps co-created by Hill et al. (2021), are aimed to be highly interactive and can be used as boundary objects to facilitate exciting discussion within and between project partners. All methods and outcomes presented in this Special Feature were used to codevelop useful and meaningful knowledge to inform current and future decision making for cultural and natural resource management at particular places and specific times. Resultant social learning can strengthen identities, increase trust, result in mutual understanding and collective agency (Hill et al. 2021).

The Special Feature also provides insights for Sustainability Science Practitioners (researchers and others). Contributors highlight the need to be mindful of where the power lies within any knowledge action system and how methodologies may reinforce or subvert power inequalities. Importantly, non-indigenous researchers and practitioners should consider themselves as 'guests in other worlds', and when they see themselves and are seen that way, they are able to contribute more effectively to those worlds (Blackett et al. 2021; Greenaway et al. 2021). Further, researchers and Indigenous leaders should be cognizant of the roles and responsibilities within any researcher partnership and/or knowledge action system, and to consider if a cultural shift is required within the community of practice. This might include open conversations about these roles and responsibilities as one way to begin to build trust, transparency and openness between partners. When researchers 'look beyond the research project' (Ruwhiu et al. 2021) they may realise their role is to support effective partnerships, to ensure multiple benefits result from different stages of the knowledge co-production process and to maintain institutional structures and process to this end (e.g., protection of Indigenous cultural and intellectual property, data sovereignty, coauthorship, payment for time). Equally, Indigenous leaders have an important role to empower each unique partnership for the benefit of their wider community (Maclean et al. 2021a). Further, all partners may consider how to determine and evaluate the success of the co-production process, this could perhaps occur via an evaluation process of the knowledge partnership itself (e.g., Robinson et al. 2021), and/or via a consideration of post-project benefits to better understand lasting impact of the knowledge action system (Maclean et al. 2021a).

The collection of papers in this Special Feature provide multiple ways to move beyond traditional research practices that perpetuate unhelpful dichotomies (e.g., 'them/us', local/global, Indigenous knowledge/Scientific knowledge) to embrace diversity and polyvocality for the development of knowledge action systems. It highlights ways to engage with the challenges of how to 'do place based' work that reflects and embraces all relevant knowledge types and systems and acknowledges related issues of colonization and environmental degradation. Insights are shared about how Sustainability Science can think and do global-local more effectively. There is much to learn from these papers as we focus on pathways to ensure sustainable futures and wellbeing across human and non-human communities.

Acknowledgements We gratefully acknowledge the CSIRO Julius Career Award that enabled Kirsten Maclean to spend time with colleagues at Manaaki Whenua Landcare Research and the NIWA (Climate, Freshwater and Ocean Science) New Zealand, and the Stockholm Environment Institute, Asia (Bangkok) to develop the community of practice, and work with co-editors Dr. Alison Greenaway and Dr. Clemens Grünbühel to develop this Special Feature. We are most grateful to the many Reviewers who provided excellent comment and critique of all papers (including this Editorial) in the Special Feature, which resulted in a much stronger contribution to the Sustainability Science Literature. We also acknowledge and pay our respects to Indigenous Elders and Leaders, past, present and emerging on whose country we each have co-conducted research past, present and will continue to do so into the future as we seek to improve our knowledge co-production processes and methodologies for more sustainable, equitable and just futures. 


\section{References}

Australian Research Council (2020) Outcomes paper: Australian and New Zealand standard research classification review 2019. Lancaster, Australian Research Council

Barber M, Jackson S, Shellberg J, Sinnamon V (2014) Working Knowledge: characterising collective indigenous, scientific, and local knowledge about the ecology, hydrology and geomorphology of Oriners Station, Cape York Peninsula, Australia. Rangel J 36(1):53-66. https://doi.org/10.1071/RJ13083

Bhattachan KB, Thapa K, Magar SKT (2020) Climate justice for indigenous women: urgency and way forward. Policy Brief AIPP, Bangkok

Blackett P, FitzHerbert S, Luttrell J, Hopmans T, Lawrence H, Colliar J (2021) Marae-opoly: supporting localised Māori climate adaptation decisions with serious games in Aotearoa New Zealand. Sustain Sci. https://doi.org/10.1007/s11625-021-00998-9

Carter L, Cosijn M, Williams LJ, Chakraborty A, Kar S (2021) Including marginalised voices in agricultural development processes using an ethical community engagement framework in West Bengal, India. Sustain Sci. https://doi.org/10.1007/ s11625-021-01055-1

Country B, Wright S, Suchet-Pearson S, Lloyd K, Burarrwanga L, Ganambarr R, Ganambarr-Stubbs M, Ganambarr B, Maymuru D, Sweeney J (2016) Co-becoming Bawaka: towards a relational understanding of place/space. Prog Hum Geogr 40(4):455-475. https://doi.org/10.1177/0309132515589437

de Sousa Santos B (2007) Another knowledge is possible: beyond northern epistemologies. Verso, London

Gibson K, Astuti R, Carnegie M, Chalernphon A, Dombroski K, Haryani AR, Hill A, Kehi B, Law L, Lyne I, McGregor A, McKinnon K, McWilliam A, Miller F, Ngin C, Occeña-Gutierrez D, Palmer L, Placino P, Rampengan M, Than WLL, Wianti NI, Wright S (2018) Community economies in Monsoon Asia: keywords and key reflections. Asia Pac Viewp 59:3-16. https://doi.org/10.1111/ apv. 12186

Greenaway A, Hohaia H, Le Heron E, Le Heron R, Grant A, Diprose G, Kirk N, Allen W (2021) Methodological sensitivities for coproducing knowledge through enduring trustful partnerships. Sustain Sci. https://doi.org/10.1007/s11625-021-01058-y

Haraway D (1988) Situated knowledges: the science question in feminism and the privilege of partial perspective. Feminist theory reader. Routledge, London, pp 303-310

Harcourt N, Awatere S, Hyslop J, Taura Y, Wilcox M, Taylor L, Rau J, Timoti P (2021) Kia Manawaroa Kia Puawai: enduring Māori livelihoods. Sustain Sci. https://doi.org/10.1007/s11625-021-01051-5

Hill R, Harkness P, Raisbeck-Brown N, Lyons I, Álvarez-Romero JG, Kim MK, Chungalla D, Wungundin H, Aiken M, Malay J, Williams B, Buissereth R, Cranbell T, Forrest J, Hand M, James R, Jingle E, Knight O, Lennard N, Lennard V, Malay I, Malay L, Midmee W, Morton S, Nulgit C, Riley P, Shadforth I, Bieundurry J, Brooking G, Brooking S, Brumby W, Bulmer V, Cherel V, Clifton A, Cox S, Dawson M, Gore-Birch C, Hill J, Hobbs A, Hobbs D, Juboy C, Juboy P, Kogolo A, Laborde S, Lennard B, Lennard C, Lennard D, Malay N, Malay Z, Marshall D, Marshall H, Millindee L, Mowaljarlai D, Myers A, Nnarda T, Nuggett J, Nulgit L, Nulgit P, Poelina A, Poudrill D, Ross J, Shandley J, Skander R, Skeen S, Smith G, Street M, Thomas P, Wongawol B, Yungabun H, Sunfly A, Cook C, Shaw K, Collard T, Collard Y (2021) Learning together for and with the Martuwarra Fitzroy River. Sustain Sci. https://doi.org/10.1007/s11625-021-00988-x

Horlings LG, Nieto-Romero M, Pisters S et al (2020) Operationalising transformative sustainability science through place-based research: the role of researchers. Sustain Sci 15:467-484. https:// doi.org/10.1007/s11625-019-00757-x
Johnson JT, Howitt R, Cajete G, Berkes F, Louis RP, Kliskey A (2016) Weaving Indigenous and sustainability sciences to diversify our methods. Sustain Sci 11(1):1-11. https://doi.org/10.1007/ s11625-015-0349-x

Le Heron E, Le Heron R, Taylor L, Lundquist CJ, Greenaway A (2020) Remaking ocean governance in Aotearoa New Zealand through boundary-crossing narratives about ecosystem-based management. Mar Policy 122:104222. https://doi.org/10.1016/j.marpol. 2020.104222

Mach KJ, Lemos MC, Meadow AM, Wyborn C, Klenk N, Arnott JC, Ardoin NM, Fieseler C, Moss RH, Nichols L, Stults M, Vaughan C, Wong-Parodi G (2020) Actionable knowledge and the art of engagement. Curr Opin Environ Sustain 42:30-37. https://doi.org/ 10.1016/jcosust.2020.01.002

Maclean K (2009) Re-conceptualising desert landscapes: unpacking historical narratives and contemporary realities for sustainable livelihood development in central Australia. GeoJournal 74:451. https://doi.org/10.1007/s10708-008-9234-9

Maclean K (2015) Cultural hybridity and the environment. Strategies to celebrate local and indigenous knowledge. Springer, Singapore

Maclean K, Bana Yarralji Bubu Inc. (2015) Crossing cultural boundaries: Integrating Indigenous water knowledge into water governance through co-research in the Queensland Wet Tropics, Australia. Geoforum 59:142-152. https://doi.org/10.1016/j.geoforum. 2014.12.008

Maclean K, Woodward E, Jarvis D, Turpin G, Rowland D, Rist P (2021a) Decolonising knowledge co production: examining the role of positionality and partnerships to support Indigenousled bush product enterprises in northern Australia. Sustain Sci. https://doi.org/10.1007/s11625-021-00973-4

Maclean K, Robinson C, Bock E, Rist P (2021b) Reconciling risk and responsibility on Indigenous country: bridging the boundaries to guide knowledge sharing for cross-cultural biosecurity risk management in northern Australia. J Cult Geogr. https://doi.org/10. 1080/08873631.2021.1911078

Massey D (1991a) A global sense of place. Marx Today, pp. 24-29

Massey D (1991b) The political place of locality studies. Environ Plan A 23:267-281

Muhammad M, Wallerstein N, Sussman AL, Avila M, Belone L, Duran B (2015) Reflections on researcher identity and power: the impact of positionality on community based participatory research (CBPR) processes and outcomes. Crit Sociol 41(7-8):1045-1063. https://doi.org/10.1177/0896920513516025

Natcher D, Owens-Beek N, Bogdan A-M, Lu X, Li M, Ingram S, McKay R, Rice A (2021) Scenario planning tools for mitigating industrial impacts on First Nations subsistence economies in British Columbia, Canada. Sustain Sci. https://doi.org/10.1007/ s11625-021-00969-0

PRADAN (2022). Who we are. https://www.pradan.net/on. Accessed 05 Jan 22

Robinson CJ, Macdonald JM, Douglas M, Perry J, Setterfield S, Cooper D, Robinson CJ, Macdonald JM, Douglas M, Perry J, Setterfield S, Cooper D, Lee M, Nadji J, Nadji S, Nayinggul A, Nayinggul A, Mangiru K, Hunter F, Coleman B, Barrowei R, Markham J, Alterson J, Moyle F, May K, Bangalang N-G (2021) Using knowledge to care for country: Indigenous-led evaluations of research to adaptively co-manage Kakadu National Park, Australia. Sustain Sci. https://doi.org/10.1007/s11625-021-01015-9

Ruwhiu D, Arahanga-Doyle H, Donaldson-Gush R, Bragg C, Kapa J, Kāti Huirapa Rūnaka ki P (2021) Enhancing the sustainability science agenda through indigenous methodology. Sustain Sci. https:// doi.org/10.1007/s11625-021-01054-2

Salamanca A, M, Biskupska N (2022) Co-creating platforms for integrating traditional ecological knowledge and conventional climate services: insights from Indonesian islands. Sustain Sci (this issue) 
Scheyvens RA, Movono A, Auckram S (2021) Pacific peoples and the pandemic: exploring multiple well-beings of people in tourismdependent communities. J Sustain Tour. https://doi.org/10.1080/ 09669582.2021.1970757

Shiva V (1993) Monocultures of the mind. Creative management and development. Sage, Thousand Oaks, p 199

Smith L (1999) Decolonizing methodologies: research and indigenous peoples. University of Otago Press, Dunedin

Tengö M, Brondizio ES, Elmqvist T, Malmer P, Spierenburg M (2014) Connecting diverse knowledge systems for enhanced ecosystem governance: the multiple evidence base approach. Ambio 43(5):579-591. https://doi.org/10.1007/s13280-014-0501-3

Tengö M, Hill R, Malmer P, Raymond CM, Spierenburg M, Danielsen F, Elmqvist T, Folke C (2017) Weaving knowledge systems in IPBES, CBD and beyond-lessons learned for sustainability. Curr Opin Environ Sustain 26-27:17-25. https://doi.org/10.1016/j. cosust.2016.12.005

Tsing AL, Deger J, Keleman Saxena A, Zhou F (2020) Feral atlas: the more-than-human anthropocene. Stanford University Press, Redwood City

Wattimena P (2018) Redefining development: a perspective from indigenous peoples in Asia. Cultural survival. Accessed 6 Nov 2018. https://www.culturalsurvival.org/news/redefining-developmentperspective-indigenous-peoples-asia

Wolf DL (1996) Situating feminist dilemmas in fieldwork. In: Wolf DL (ed) feminist dilemmas in fieldwork. Westview Press, USA, pp $1-55$

Woodward E, McTaggart PM (2019) Co-developing Indigenous seasonal calendars to support 'healthy country, healthy people' outcomes. IUHPE- Glob Health Promot 26(3):26-34. https://doi. org/10.1177/1757975919832241

Woodward E, Jackson S, Finn M, Marrfurra McTaggart P (2012) Utilising Indigenous seasonal knowledge to understand aquatic resource use and inform water resource management in northern Australia. Ecol Manag Restor 13:58-64

Woodward E, Hill R, Harkness P, Archer R (2020) Our knowledge our way in caring for Country: indigenous-led approaches to strengthening and sharing our knowledge for land and sea management. Best Practice Guidelines from Australian experiences, NAILSMA and CSIRO. Avaliable from https://www.csiro.au/en/ research/indigenous-science/Indigenous-knowledge/Our-Knowl edge-Our-Way/OKOW-resources

Zurba M, Maclean K, Woodward E, Islam D (2019) Amplifying Indigenous community participation in place-based research through boundary work. Prog Hum Geogr 43(6):1020-1043. https://doi. org/10.1177/0309132518807758

Zurba M, Petriello MA, Madge C, McCarney P, Bishop B, McBeth S, Denniston M, Bodwitch H, Bailey M (2021) Learning from knowledge co-production research and practice in the twentyfirst century: global lessons and what they mean for collaborative research in Nunatsiavut. Sustain Sci. https://doi.org/10.1007/ s11625-021-00996-x

Publisher's Note Springer Nature remains neutral with regard to jurisdictional claims in published maps and institutional affiliations. 